\title{
A Crispy Delicacy: Augosoma Beetle as Alternative Source of Protein in East Cameroon
}

\author{
F. J. Muafor, ${ }^{1,2}$ P. Levang, ${ }^{3,4}$ and P. Le Gall ${ }^{5,6}$ \\ ${ }^{1}$ Living Forest Trust (LIFT), c/o BP 1857, Yaoundé, Cameroon \\ ${ }^{2}$ Ministry of Forestry and Wildlife (MINFOF), BP 34430, Yaoundé, Cameroon \\ ${ }^{3}$ Center for International Forestry Research (CIFOR), BP 2008, Yaoundé, Cameroon \\ ${ }^{4}$ Institut de Recherche pour le Développement (IRD), UMR 220 GRED, 911 avenue agropolis, BP 64501, \\ 34394 Montpellier Cedex 5, France \\ ${ }^{5}$ Institut de Recherche pour le Développement (IRD), UR 072, BP1857 Yaoundé, Cameroon \\ ${ }^{6}$ Laboratoire Evolution, Génomes et Spéciation, UPR 9034, Centre National de la Recherche Scientifique (CNRS), \\ 91198 Gif-sur-Yvette Cedex, France et Université Paris-Sud 11, 91405 Orsay Cedex, France \\ Correspondence should be addressed to F. J. Muafor; muaforl@yahoo.com
}

Received 4 October 2013; Accepted 2 November 2013; Published 28 January 2014

Academic Editor: Rafael Riosmena-Rodríguez

Copyright (c) 2014 F. J. Muafor et al. This is an open access article distributed under the Creative Commons Attribution License, which permits unrestricted use, distribution, and reproduction in any medium, provided the original work is properly cited.

\begin{abstract}
Despite the fact that the exoskeleton of the Augosoma centaurus (Dynastinae) is hard and difficult to chew, this insect is often gathered in Eastern Cameroon for food in periods of availability. Nine ethnic groups in Eastern Cameroon were surveyed to understand the role of this insect in assuring food security, using quantitative and qualitative social science approaches. Both the larvae and adult stages of this beetle are habitually consumed in the areas studied. In total, about $65 \%$ of consumers prefer consuming the adults, while $35 \%$ prefer consuming the larvae. About $24 \%$ of consumers derive the same satisfaction from the consumption of Augosoma or other edible insects. Close to 39\% of consumers prefer other edible insects to Augosoma, while $37 \%$ prefer the consumption of Augosoma to other edible insects. This beetle usually occurs at a period when other edible insects are not available, therefore constituting a good source of alternative protein in this region where poverty, poaching, and biodiversity erosion are still a major problem. Furthermore, the gathering of this beetle for food is equally a means of biological pest control of raffia plants and a tool to enhance community-based conservation of the areas global biodiversity.
\end{abstract}

\section{Introduction}

Edible insects are important forest resources that contribute to livelihoods in most regions across the world. Although forest insects are usually less mentioned amongst traditional nontimber forest products (NTFPs), they play a great role in livelihood improvement in most developing countries [1]. Apart from the fundamental contribution of forest insects to pollen dissemination and forest ecosystems stability, they constitute an important source of protein to forest dependent people in many parts of developing tropical countries $[2,3]$. Some insects are also used as medicine in many traditional medical and/or sometimes modern medical practices [4]. In Africa, Asia, and Latin America, hundreds of forest insect species are used as human food [5]. In Sub-Saharan
Africa where many poor people can hardly afford ordinary sources of protein like meat and fish, insects occupy an important place in rural food security. However, authors have different views on the extent to which forest insects can contribute to food security in the Sub-Saharan Africa region. According to FAO, forest insects are important NTFPs that are mostly gathered by poor people for food, particularly women and children [6]. De Foliart considers forest insects as an occasional delicacy that is used as food replacement in times of shortages, droughts, floods, and war [7]. These views are completely different from those of Banjo, who reported that forest insects are ordinarily not only gathered by the poor or used as emergency food during shortages, but also included as a planned part of the diet throughout the year or when seasonally available [5]. 
However, knowledge is lacking on the actual number of insects that are eaten as food, though some authors have provided estimates that are quite enthralling. According to De Foliart, about 1000 species of insects are eaten worldwide [7]. Ramos-Elorduy indicates that about 1391 species of insects are eaten worldwide, of which 524 are eaten in 34 countries of Africa, representing 38\% of all species consumed [8]. Nonetheless, amongst the different groups (taxa) of insects that are eaten in Sub-Saharan Africa, grasshoppers, locusts, caterpillars, palm beetle grub, and termites are the most popular $[9,10]$. The nutrient value of some of these insects is very high. Malaisse gives an overview of the nutritional values of various caterpillar species [11]. The trade of these insects, although seasonal, provides rural dwellers with additional household income [12]. Tabuna looks at the role of edible caterpillars (Imbrasia spp.) as source of income in SubSaharan Africa [13]. However, though few studies have been done to estimate the financial contribution of edible insects to rural income, very little is known on the financial potentials of many species of endemic and/or rare nonedible forest insects like beetles, notably: the white forms of Goliathus goliatus (Linnaeus, 1771), Stephanocrates preussi (Kolbe, 1892), and Fornasinius aureosparsus (Van de Poll, 1890) which are largely gathered in some parts of Sub-Saharan Africa for international pet and insect collectors trade and which are currently an important source of rural income in Cameroon montane forest regions [1].

In the east region of Cameroon, beetles are exploited not only for trade, but also for food. The Augosoma centaurus (Fabricius, 1775) beetle in particular is eaten both in its larvae and adult stages. Across the forest region of East Cameroon, this beetle is mainly gathered as cultural delicacy in periods of availability. This beetle is amongst the biggest of the family Dynastinae in Africa and they measure between $40 \mathrm{~mm}$ and $90 \mathrm{~mm}$ in length. The males show cephalic and thoracic horns. The females are similar to the males, except that they have no horns and the lengths of the anterior tibia are shorter. The genus Augosoma is the only representative of the Dynastini tribe in Africa and is represented by two species: Augosoma centaurus and Augosoma hippocrates. The Augosoma centaurus is largely distributed across tropical Africa, from $10^{\circ} \mathrm{N}$ to $10^{\circ} \mathrm{S}$, especially in the forested parts of Guinea, Ivory Coast, Ghana, Togo, Benin, Nigeria, Cameroon, DRC, and Congo, while Augosoma hippocrates is localized in Gabon [14]. In most cases, Augosoma centaurus occurs in very large numbers and can constitute a major pest to some forest plant species like palms, coconut, and eucalyptus $[15,16]$. The adults feed on the apical buds, while the larvae bore into the stems of raffia and other palm species. Adult individuals are usually attracted to light in villages at the edge of forests, where they are easily gathered by simple hand-picking. They occur generally at the beginning of the dry season, constituting, therefore, a potential source of protein at a period when other groups of edible insects like caterpillars, grasshoppers, and termites are no longer available in the area. This paper describes the use of Augosoma centaurus as alternative sources of protein in the east region of Cameroon.

\section{Material and Methods}

2.1. Description of the Study Area. The study was conducted in 10 subdivisions of the east region of Cameroon; notably, Yokadouma, Salapoumbe, Gari-Gombo, Diang, Belabo, Batouri, Ndellele, Mandjou, Dimako, and Doumé subdivisions. The east region has a total surface area of about $109,011 \mathrm{~km}^{2}$ and is bounded to the east by the Central African Republic, to the south by Republic of Congo, to the north by the Adamaoua Region, and to the west by the Centre and South Regions. According to history, the peoples of this region have been settled in Cameroonian territory for longer than any other of the country's many ethnic groups, the first inhabitants being the Baka pygmies [17]. The climate of this region is of wet equatorial type (Guinea climate type). Temperatures are high $\left(24^{\circ} \mathrm{C}\right.$ on average), with four seasons, a long dry season from December to May, a light rainy season from May to June, a short dry season from July to October, and a heavy rainy season from October to November. Humidity and cloud cover are relatively high, and precipitation averages $1500-2000 \mathrm{~mm}$ per year except in the extreme eastern and northern parts, where it is slightly less.

The region contains several river systems, amongst which the Nyong, which drains the central-western area, the Dja in the southwest, the Lom in the northeast, the Kadei (Kadei), which drains the northwest, the Boumba in the centre and southeast, and the Sangha and Ngoko, which drain portions of the southeast and form the border with the Central African Republic and Congo, respectively. The Lom and Nyong rivers flow into the Atlantic Ocean, while all the others form part of the Congo River basin. The vegetation of the area is predominantly that of a rain forest type. The forests are dominated by hardwood evergreen species, some of which grow to heights of 70 meters or more, such as Ayous (Triplochiton scleroylon), Sapelli (Entandrophragma cylindricum), Fraké (Terminalia superba), Tali (Erytrophleum ivorense), Kotibé (Nesogordia papaverifera), Kosipo (Entandrophragma candolei), Dibetou (Lovoa trichilioides), Padouk rouge (Pterocarpus soyauxii), Eyong (Eribloma oblongum) and Diana (Celtis zenkeri). Nonetheless, the portion of the region between Bertoua and Batouri is dominated by humid, wooded savannah and trees here are sparser but still may grow to be as tall as 20 meters [18].

2.2. Field Methods. Data were collected by four field investigators during two field trips between November 2012 and February 2013. In each of the subdivisions, villages were randomly selected and surveyed through the help of participatory rural appraisal (PRA) tools like semistructured questionnaires, interviews, and field observations. In each of the villages sampled, at least $30 \%$ of the population were surveyed. Respondents were basically men and women of age above 18 years. In total, 350 semistructured questionnaires were distributed. In case of grouped interview, open oral discussion on issues related to Augosoma consumption was engaged with the group. In either case, questions were asked on the consumption, trade, harvesting, preparation, marketing, and host plant species of Augosoma (larvae and adults), as well as the preference of Augosoma consumption 
TABle 1: Vernacular names of Augosoma beetle in the villages surveyed.

\begin{tabular}{|c|c|c|c|c|}
\hline Subdivision & Villages & Ethnic group & Vernacular names of adult & Vernacular names of larvae \\
\hline Salapoumbe & Salapoumbe & Baka & \multirow{2}{*}{ Angombo } & Kpulu \\
\hline Yokadouma & Yokadouma & Mbimo & & Gogoro \\
\hline Yokadouma & Ngatto & Konabembe & Angombo & Penbe \\
\hline Dimako & Kwen & Bakoum & \multirow{2}{*}{ Kouala } & \multirow{2}{*}{ Bekouala } \\
\hline Doumé & Petitpaki & Bakoum & & \\
\hline Belabo & Ndemba II & Bobilis & \multirow{3}{*}{ Goubla } & \multirow{3}{*}{ Bikuta } \\
\hline Belabo & Belabo & Bobilis & & \\
\hline Belabo & Essendjane & Bobilis & & \\
\hline Batouri & Tikonde & Kakor & Angomkumbo & Kwatto \\
\hline Ndellele & Ngotto & Kakor & \multirow{2}{*}{ Angiyong } & Nakumbe \\
\hline Gari Gombo & Weso & Kakor & & Kuru \\
\hline Diang & Mbwam & Makaa du Nord & Goubla (Bola) & Mekuma \\
\hline Mandjou & Mboulaye I & Baya & \multirow{3}{*}{ Abankubu (Agwankubu) } & \multirow{3}{*}{ Andossi } \\
\hline Mandjou & Ndoumbé & Baya & & \\
\hline Mandjou & Adingkal & Baya & & \\
\hline
\end{tabular}

to other edible insects like caterpillars, grasshoppers, locusts, and the palm beetle grub.

2.3. Data Analysis. Collected data were analyzed using Excel 7.0 and SPSS software. In order to facilitate the analysis, themes emerging from the interviewee responses were coded. For each question, a separate running list of codes was reserved and new codes created as new themes emerged. The same codes were used for similar themes or issues in order to eliminate conceptual redundancies. This coding process allowed the answers given in narrative form to be listed in the form of one word or a short phrase in order to facilitate analyses.

\section{Results}

3.1. The Range of Consumption and Vernacular Appellation of Augosoma in East Cameroon. The Augosoma beetle is a delicacy in the east region of Cameroon. At least 16 villages including Salapoumbe, Ngatto, Kwen, Petitpaki, Ngotto, Essendjiane, Wesso, Ndemba II, Tikonde, Ngounté, Mbwam, Mboulaye I, Ndoumbé, Adingkal, Yokadouma, and Belabo were identified as important areas where the Augosoma beetle is eaten (Figure 1). The Augosoma beetle is eaten in both its larvae (grub) and adult stages.

The western part of this province (Messamena, Somalomo, and Lomie) was not surveyed and no information is available on whether the Augosoma beetle is eaten in these areas. Other areas which were not surveyed but which were equally reported to be important zones for Augosoma beetle consumption include the Doumaintang, Mboma, Angossas, and Moloundu neighborhoods. In addition to the Augosoma beetle, other forest insects which are equally consumed as cultural delicacy in the east region of Cameroon include caterpillars, palm beetle grubs, termites, grasshoppers, and crickets. The villages sampled belong to nine tribes, notably:

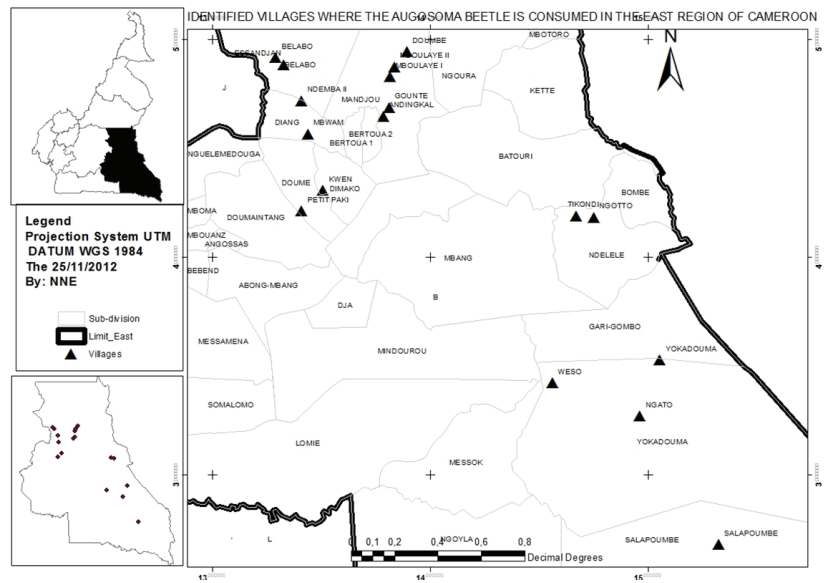

FIGURE 1: Identified villages where the Augosoma beetle is consumed in East Cameroon.

Konabembe, Baka, Bagando, Kakor, Mbimo, Makaa du Nord, Bobilis, Kakor, Baya, and Bakoum. Each of the villages has a vernacular name for the adult and larvae stages of the Augosoma beetle (Table 1).

The vernacular names of adult or larvae stages of the beetle are the same in neighbouring villages within the same ethnic group. However, the appellation of the adult and larvae individuals might vary by a simple addition of the prefix "Be" to the appellation of adult. People of the Bakoum tribe, for example, call the adult Augosoma "Kouala" and the larvae "Bekouala." In some villages, the beetle is named based on the appellation of dominant immigrant population from neighbouring tribes. This is the case of the Mbwam village of the Makaa du Nord ethnic group where the adult Augosoma beetle is named "Goubla," following the appellation of the dominant immigrant population from the Bobilis communities. 


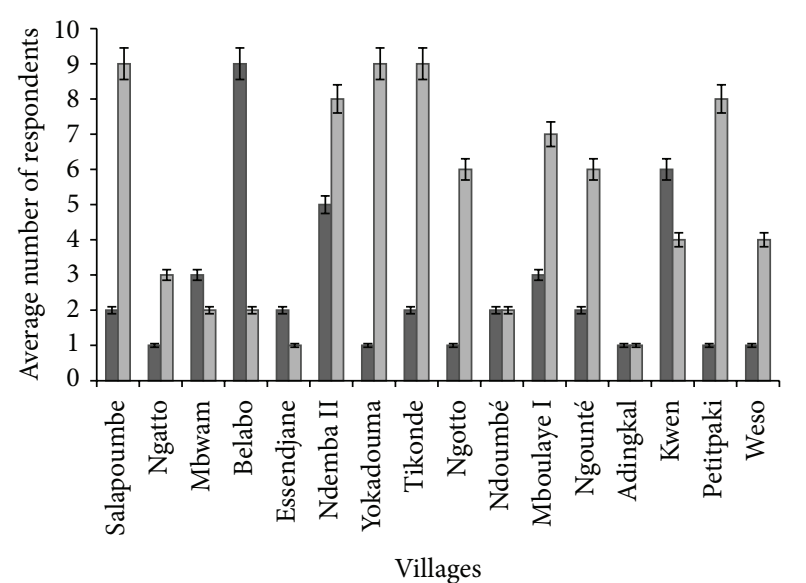

- Larva

口 Adult

Figure 2: Consumption preference between Augosoma larvae and adults in the different groups.

3.2. Consumption Preference of Augosoma Larvae and Adult. Compared to other edible insects like caterpillars, palm beetle grubs, termites, locusts, and grasshoppers, about $37 \%$ of respondents prefer the consumption of Augosoma. Close to $24 \%$ of respondents derive the same satisfaction in consuming either the beetle or any other edible insects. On the contrary, $39 \%$ of respondents appreciate less the consumption of Augosoma, compared to other edible insects. Though the proportion of people that consume the Augosoma beetle is high, the level of consumption of larvae and adult is, however, not the same in the different villages and ethnic groups. In some villages, people prefer consuming the larvae while, in others, the adults are highly appreciated (Figure 1).

Villages of the Kakor, Baya, Mbimo, Konabembe, Bakoum, Bagando and Baka ethnic groups consume more the adult Augosoma beetle, while those of the Bobilis (Belabo, Essendjane, and Kwen) and Makaa du Nord (Mbwam) prefer consuming the beetle in its larvae stage. In total, about $65 \%$ of consumers prefer consuming the adults, while $35 \%$ prefer consuming the larvae, despite the fact that the skin of the cooked larvae is hard and quite difficult to chew (Figure 2).

3.3. Period of Occurrence and Harvesting Methods. The adult Augosoma beetle is seasonal and they occur between the months of November and December. According to respondents, this insect usually occurs at a period when most species of other edible insects are not available (Table 2).

However, the abundance of this insect varies from year to year and there is usually an outbreak of its population every two years. The larvae of the beetle, however, are available yearround and can be gathered whenever need be. The adults are harvested on electrified spots at night or on locally known Augosoma attracted (host) plant species like raffia (Raphia sp.) and Pandanus (Pandanus candelabrum). Adults attracted to light are gathered by simple hand-picking when they settle on the ground or on objects around the electrified spots.

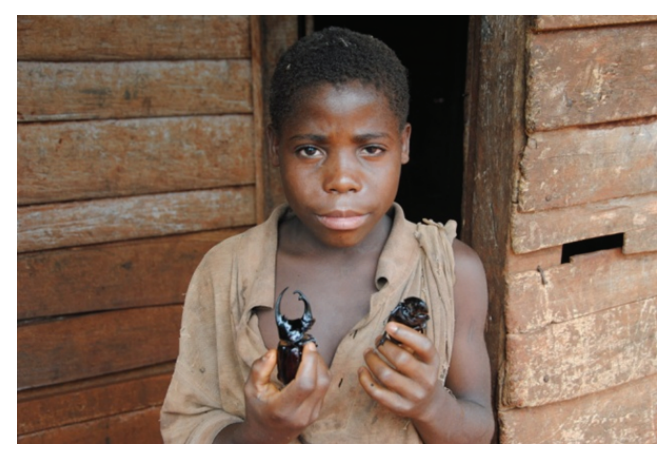

FIGURE 3: Baka child with a couple of Augosoma beetles.

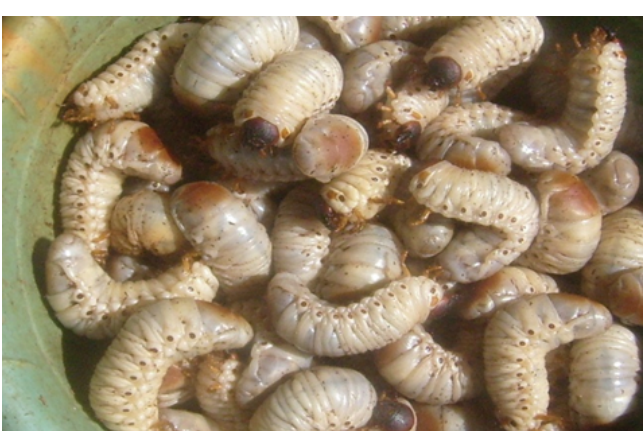

FIgURE 4: Stock of harvested Augosoma larvae.

Large amounts of adult Augosoma beetle are collected by this method, especially in forest logging areas where good public lamps have been installed by logging companies. In seasons of abundance, a single collector can fill a bucket of 5-litter capacity in a single night of effective gathering. The beetles are equally collected directly from their host plant species (raffia and Pandanus). In this case, local people walk across the swampy forest of raffia or Pandanus and observe the buds and stems of the plants. Once a beetle is seen on a plant, it is collected by simple hand-picking (Figure 3 ).

This technique of harvesting does not allow for large stock gathering because the plants are sometimes tall and collectors cannot easily reach the height at which the beetles are situated. Consequently, close to $77 \%$ of adult Augosoma beetles are gathered from electrified spots at night, while 23\% are gathered from host plant species. The larvae (grub) of the beetle are collected on dead plant stems, especially dead stems of raffia and Pandanus. To gather the larvae, local people identify dead stems of host plants which they split to collect the larvae by hand-picking. For a few hours of gathering, a single person can collect large quantity of larvae from a dead stem of raffia (Figure 4). The activity is, however, quite difficult and requires a lot of effort. About $33 \%$ of collectors are children, $20 \%$ males, and $47 \%$ females.

3.4. Marketing of Augosoma Beetles. The Augosoma beetle is not marketed at a very large scale as is the case for some caterpillars, grasshoppers, termites, and the palm beetle grub. However, both the larvae and the adults of the Augosoma beetle are sold at a small scale in each of the villages surveyed. 
TABLe 2: Periods of availability of Augosoma beetle compared to other edible insects in the East region of Cameroon.

\begin{tabular}{|c|c|c|c|c|c|c|c|c|c|c|c|c|}
\hline Common names & January & February & March & April & May & June & July & August & September & October & November & December \\
\hline Caterpillars & & & & & & & $\sqrt{ }$ & $\sqrt{ }$ & $\sqrt{ }$ & & & \\
\hline Palm beetle grub & $\sqrt{ }$ & $\sqrt{ }$ & $\sqrt{ }$ & $\sqrt{ }$ & $\sqrt{ }$ & $\sqrt{ }$ & $\sqrt{ }$ & $\sqrt{ }$ & $\sqrt{ }$ & $\sqrt{ }$ & $\sqrt{ }$ & $\sqrt{ }$ \\
\hline Adult Augosoma & & & & & & & & & & & $\sqrt{ }$ & $\sqrt{ }$ \\
\hline Augosoma larvae & $\sqrt{ }$ & $\sqrt{ }$ & $\sqrt{ }$ & $\sqrt{ }$ & $\sqrt{ }$ & $\sqrt{ }$ & $\sqrt{ }$ & $\sqrt{ }$ & $\sqrt{ }$ & $\sqrt{ }$ & $\sqrt{ }$ & $\sqrt{ }$ \\
\hline Termites & & & $\sqrt{ }$ & $\sqrt{ }$ & $\sqrt{ }$ & & & & & & & \\
\hline Grasshoppers & & $\sqrt{ }$ & $\sqrt{ }$ & $\sqrt{ }$ & & & & & & & & \\
\hline Locusts & & & $\sqrt{ }$ & $\sqrt{ }$ & & & & & & & & \\
\hline
\end{tabular}

TABLE 3: Local market prices of Augosoma, compared to other edible insects in the east region of Cameroon.

\begin{tabular}{lccc}
\hline Edible insect & Quantity & Local market price (in FCFC) & Local market price (in Euro) \\
\hline Palm beetle grub & 1 glass full (about 20 pieces) & $300-500$ & $0,46-0,76$ \\
Caterpillars & 1 glass full (about 15 to 45 pieces) & $200-300$ & $0,30-0,46$ \\
Augosoma beetle & 1 piece (uncooked) & 25 & 0,038 \\
Augosoma larvae & 6 pieces (uncooked) & 100 & 0,15 \\
\hline
\end{tabular}

They are either sold raw or cooked. Adult Augosoma beetles are sold at 25 FCFA $(0,038 €)$ a piece on average when raw and 50 FCFA $(0,076 €)$ a piece when cooked in most villages, while the larvae are sold at 100 FCFA $(0,15 €)$ for 6 pieces raw on average and 4 pieces cooked. In some villages along the Yaoundé-Bertoua highway, for example, the larvae of the Augosoma beetle are commonly sold alongside the palm beetle grub in the form of brochette. Though the market chain of the Augosoma beetle is not as large as that of other groups of edible insects, local market prices of the Augosoma beetle are quite high, compared to the prices of other groups of commercialized edible insects like the palm beetle grub and caterpillars, for example (Table 3 ).

3.5. Preparation of the Augosoma Beetle for Food. Both the larvae and the adult Augosoma beetles are cooked before consumption. The cooking process for adults begins by the elimination of the legs, elytra, wings, and abdominal waste. For the larvae, the waste content of the abdomen and at times the head are equally removed. The beetle is then washed, boiled, and fried with spices or cooked in a soup. The cooked beetle is usually accompanied with plantains, cocoyam, and cassava fufu. Though the taste of the larva is highly appreciated by many consumers, the skin of this larva is hard and difficult to chew.

\section{Discussion}

4.1. Myths Associated with Augosoma Consumption in Eastern Cameroon. Edible insects, like other nontimber forest products, are fundamental to rural livelihoods in Cameroon. The Augosoma beetle in particular is consumed by many indigenous people of the east region. The consumption of the Augosoma beetle in its adult stage is associated with many myths in some ethnic groups. Some consumers believe that the hard exoskeleton of the adult beetle can fortify bones. Therefore, the consumption of adult Augosoma beetle will favour the development of bones, especially in children where the beetles are usually provided to make them walk faster. In some villages of the Kakor tribe, it is also believed that the consumption of the adult beetle increases sexual resistance, making it possible for an adult to better satisfy his partner during at-bedtime. Owing to the cultural values associated to this beetle, the consumption of adults in the past was only reserved to those initiated [19]. Others believe it is a cheap source of protein that can supply the body with special nutrients (vitamins and minerals). This native belief on the nutrient value of edible insects has been proven scientifically in the case of caterpillars, found to be a complementary source of lysine to the cereal consuming communities of the Democratic Republic of Congo [20]. Insects are a good source of micronutrients, especially minerals and vitamins [21]. Some are very rich in iron $(\mathrm{Fe})$ and vitamins $\mathrm{A}$. Insects have proven to contain even more bioefficacious micronutrients than vegetables [22].

4.2. Impact of Augosoma Consumption on Insect Pest Effect. The exploitation of Augosoma for food not only offers an opportunity to complement nutrient requirements in East Cameroon, but also serves as a means of biological pest control of raffia plants. The larvae of the Augosoma beetle live and feeds on this plant species which is of high importance. Raffia plants play an important role in maintaining the ecological functions of swamp forest ecosystems. They equally have exceptional socioeconomic and cultural values in the east region. Various products and subproducts obtained from raffia plants benefit local poor communities in different ways. The leaves, stems, bamboo and sap of the raffia are traditionally harvested as nontimber forest products. The Augosoma pest action affects the health of swampy raffia forest and in turn affects the livelihoods of raffia dependent populations. These attacks bring about morphological changes that reduce the vitality/growth or cause the death of raffia plant. Nonetheless, insect attacks on the stems of raffia and other palms are not caused only by the Augosoma beetle. Other Dynastidaes, like Oryctes species and the palm weevil 
(Rhynchophorus phoenicis (Linnaeus, 1758)) are equally potential pest of raffia species. Combined feeding and reproductive activities of these insects can lead to enormous lost in the productivity of palm trees [15]. In addition to biological pest control, the gathering of Augosoma for food provides an opportunity for rural livelihood improvement, while preventing the possible use of toxic chemicals to fight the pest effect of the insect species on raffia palms.

\subsection{Potentials of Entomophagy on Biodiversity Conservation} in East Cameroon. The exploitation of edible insects contributes to food security, poverty alleviation, and improved livelihood in the east region of Cameroon. It equally contributes to biodiversity conservation in the region, considering the fact that local people exploit insects as alternative sources of protein and income. In most part of this region, local people substitute meat and fish with edible insects when they are seasonally abundant. Consequently, bush meat harvest and pressure on wildlife are likely to decrease in seasons when edible insects are harvested. The consumption of Augosoma in particular can be considered as a potential alternative in rural livelihood in forest management in the east region, considering the fact that both the larvae and adult individuals of this beetle are a delicacy, they are periodically abundant, the adults are easily gathered in electrified areas, and the larvae are harvested on dead plant stems. The harvesting process of this beetle (both adult and larvae) is less destructive to the forest and it helps in reducing the pest effect of the Augosoma beetle. The larvae of the Augosoma beetle are available all long the year, while the adults are available in periods when other edible insects are no longer available. The integration of local gathering practices of the Augosoma beetle and other forest insects to sustainable forest management practices will reinforce forest sustainability in the east region and Cameroon as a whole.

\section{Conclusion}

The consumption of the Augosoma beetle is part of the cultural heritage of most tribes in the east region of Cameroon. The gathering of this beetle for food contributes to food security, poverty alleviation, livelihood improvement, and pest control in the region. However, the habit of consuming this beetle is gradually declining and these insects are less considered as useful nontimber forest resources. With increasing need for alternatives to tackle the world major problems (poverty, food security, biodiversity erosion, climate change, etc.), the potentials of this insect as nontimber forest product need to be reconsidered. It is, therefore, vital for these insects to be better valorised and integrated to local forest management and conservation schemes. In some parts of Africa, edible insects are fully integrated in the participative forest management practices. In Malawi, for example, farmers adjacent to Kasungu National Park are allowed to harvest edible insects at certain times in the Park to diversify their income. So doing the Park management wins the support of resident communities for wildlife conservation programs [22]. By allowing rural people to use protected areas in this way in the east region, the preservation of the country's biodiversity will be enhanced, since developing the consumption of forest insects will sustain the socioeconomic and ecological functions of forest ecosystem, thereby reducing anthropic impact on global biodiversity. However, additional researches are needed to understand the nutrient value of both the larvae and the adults, as well as the effect of their consumption on human health.

\section{Conflict of Interests}

The authors declare that there is no conflict of interests regarding the publication of this paper.

\section{Acknowledgments}

The authors are very grateful to all respondents who accepted providing them with information. Special thanks go to Kamgang Roger, Nanfack Nguimgo Alix Carine, and Keng Hanry Joel for their devotion and determination during field data collection. Thanks are due to to Yakeu Serge Eric and Nsoh Ndam Elvis for their respective contribution to the study.

\section{References}

[1] F. J. Muafor, P. Levang, and P. le Gall, "Making a living out of forest insects: beetles as income source in Southwest Cameroon," International Forestry Review, vol. 14, no. 3, pp. 314325, 2012.

[2] FAO, Non-Wood Forest Products for Rural Income and Sustainable Forestry, Non-Wood Forest Products 7, FAO, Rome, Italy, 1995.

[3] J. Stack, A. Dorward, T. Gondo, P. Frost, F. Taylor, and N. Kurebgaseka, "Mopane worm utilization and rural livelihoods in Southern Africa," in Proceedings of the International Conference on Rural Livelihoods, Forests and Biodiversity (CIFOR '03), Bonn, Germany, 2003.

[4] R. Lupoli, L'insecte Médicinal, Ancyrosoma, Fontenay sous Bois France, 2010.

[5] A. D. Banjo, O. A. Lawal, and E. A. Songonuga, “The nutritional value of fourteen species of edible insects in southwestern Nigeria," African Journal of Biotechnology, vol. 5, no. 3, pp. 298301, 2006.

[6] G. R. DeFoliart, "An overview of the role of edible insects in preserving biodiversity," Ecology of Food Nutrition, vol. 36, no. 2-4, pp. 109-132, 1997.

[7] J. Ramos-Elorduy, "Insects: a sustainable source of food?" Ecology of Food Nutrition, vol. 36, no. 2-4, pp. 247-276, 1997.

[8] E. Dounias, "L'exploitation méconnue d'une ressource connue: la récolte des larves comestibles de charançons dans les palmiers raphia au Cameroun," Présentation orale, 1999.

[9] G. N'Gasse, “Contribution des chenilles/larves comestibles à la réduction de l'insécurité alimentaire en République centrafricaine (RCA)," Rapport de Consultation, FAO, Rome, Italy, 2003.

[10] F. Malaisse, Se Nourrir en Forêt Claire Africaine. Approche Écologique et Nutritionnelle, Les Presses agronomiques de Gembloux, Gembloux, Belgique, 1997. 
[11] P. Vantomme, D. Göhler, and F. N'deckere-Ziangba, "Contribution of forest insectsto food security and forest conservation: the example of caterpillars in Central Africa," ODI Wildlife Policy Briefing n³, 2004, http://www.odi-bushmeat.org/wildlife_policy_briefs.htm.

[12] H. Tabuna, Evaluation des Échanges des Produits Forestiers non Ligneux Entre l'Afrique Subsaharienne et l'Europe, FAO, Rome et CARPE (Central African Regional Program for the Environment), USAID, 2000.

[13] L. Milani, "Una nuova specie di Augosoma Burmeister dal Gabon (Coleoptera, Scarabaeidae, Dynastinae)," Giornale Italiano di Entomologia, vol. 7, pp. 267-271, 1995.

[14] P. Venard-Combes and D. Mariau, "Augosoma centaurus, Fabricius (Coleoptera Scarabeidae) important ravageur du cocotier en Afrique Descriptions, biologie, méthode de lutte," Oléagineux, vol. 38, no. 12, pp. 651-657, 1983.

[15] M. Diabangouaya, Entomofaune des plantations industrielles d'Eucalyptus des savanes côtières du Congo: cas d'Helopeltis schoutedeni Reuter (Heteroptera miridae) déprédateur des jeunes plantations [Thèse doctorat], Université Paris-Sud Orsay, 1994.

[16] V. G. Fanso, Cameroon History for Secondary Schools and Colleges, Vol. 1: From Prehistoric Times to the Nineteenth Century, Macmillan Education Ltd, Hong Kong, 1989.

[17] R. Letouzey, Note Phytogéographique du Cameroon, Encyclopédie Biologique, Paris, France, 1968.

[18] G. Tessmann, Die Pangwe, vol. 1-2, E. Wasmuth, Berlin, Germany, 1913.

[19] K. K. Kodondi, M. LeClercq, and F. Gaudin-Harding, "Vitamin estimations of three edible species of Attacidae caterpillars from Zaire," International Journal for Vitamin and Nutrition Research, vol. 57, no. 3, pp. 333-334, 1987.

[20] S. G. F. Bukkens, "The nutritional value of edible insects," Ecology of Food Nutrition, vol. 36, no. 2-4, pp. 287-319, 1997.

[21] A. Van Huis, "Insects as food in Sub-Saharan Africa," Insect Science and its Application, vol. 23, no. 3, pp. 163-185, 2003.

[22] S. M. Munthali and D. E. C. Mughogho, "Economic incentives for conservation: beekeeping and Saturniidae caterpillar utilization by rural communities," Biodiversity and Conservation, vol. 1, no. 3, pp. 143-154, 1992. 

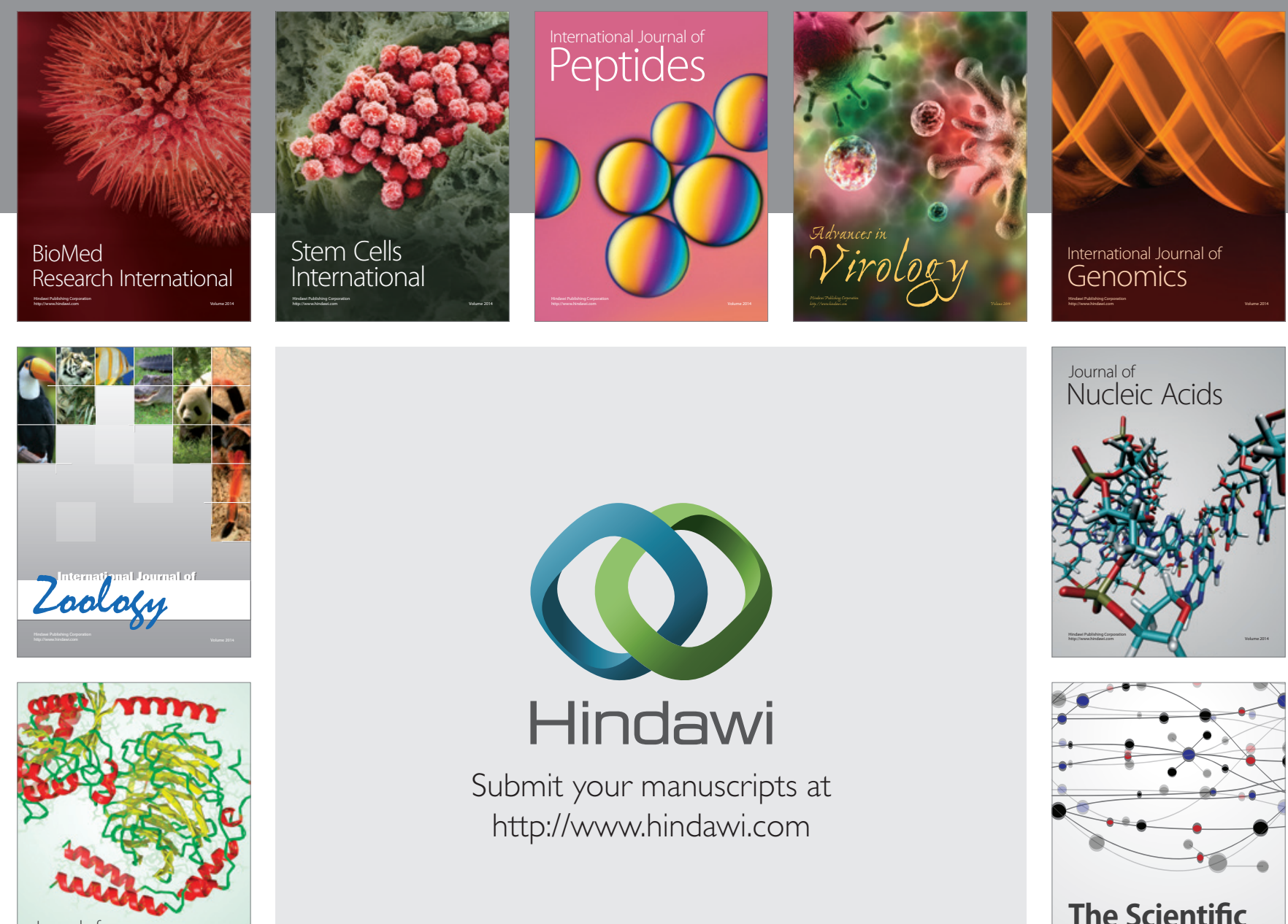

Submit your manuscripts at

http://www.hindawi.com

Journal of
Signal Transduction
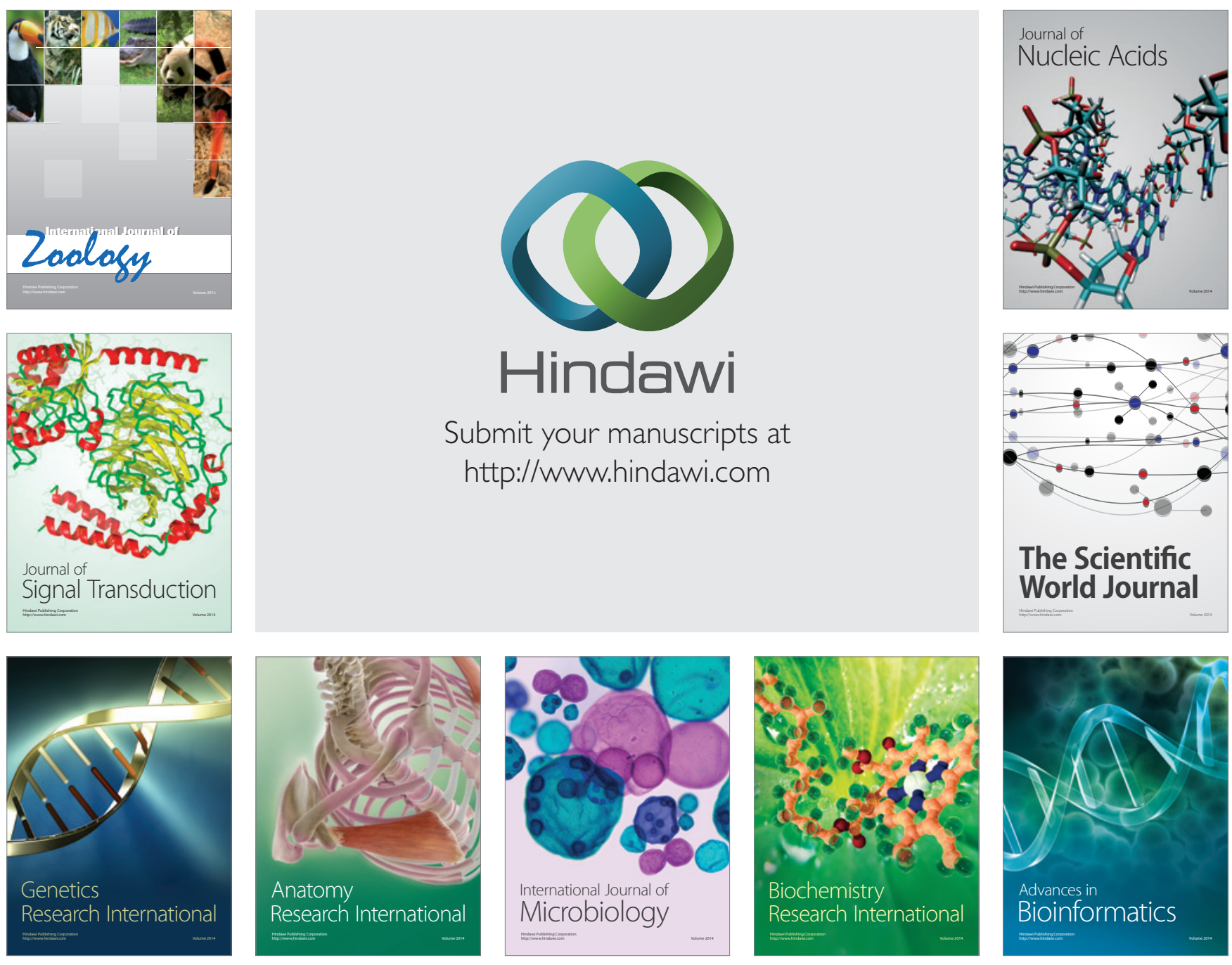

The Scientific World Journal
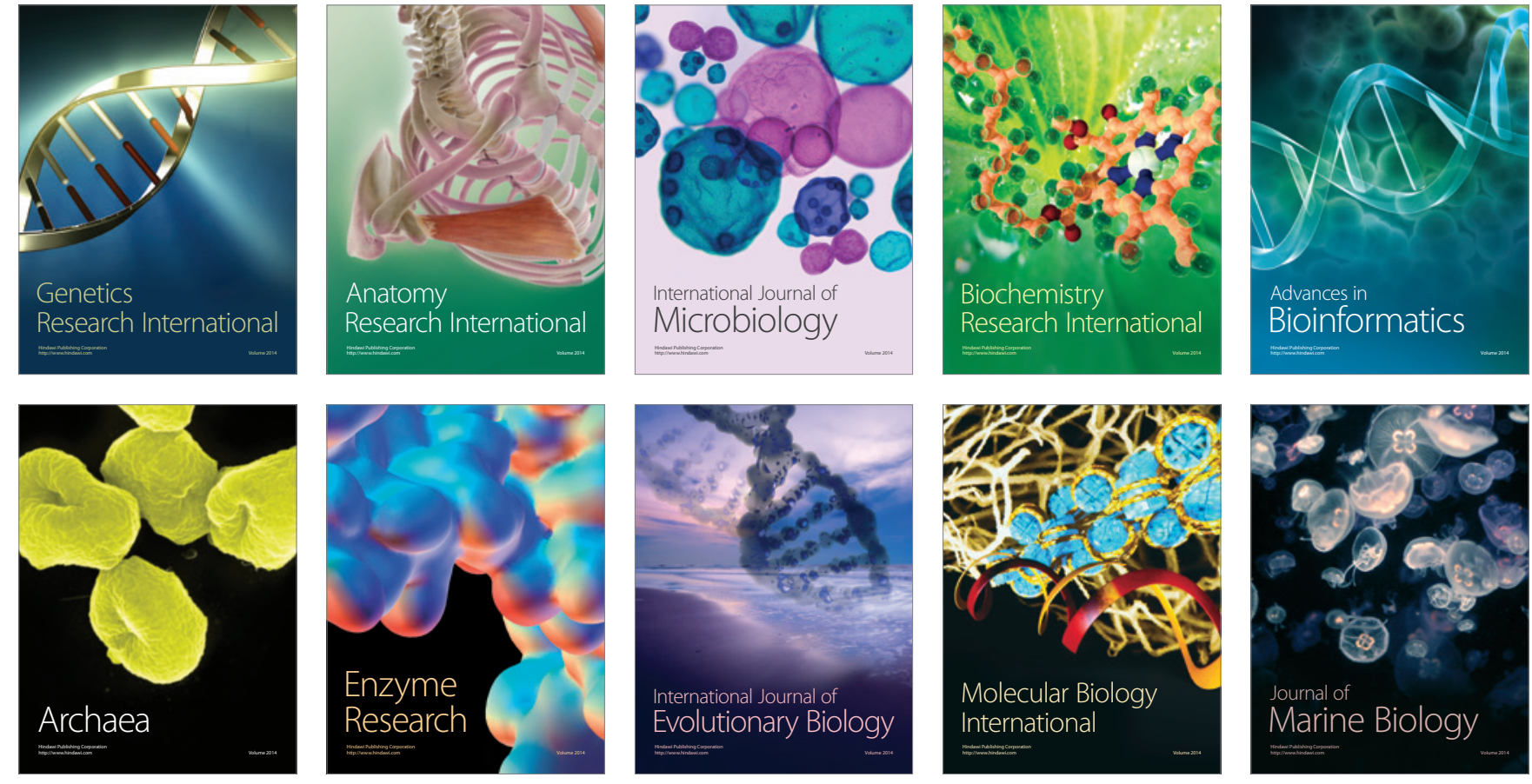